\author{
Monika Wyszomirska ${ }^{\text {* }}$ \\ a) Scientific and Research Centre for Fire Protection - National Research Institute / Centrum Naukowo-Badawcze Ochrony \\ Przeciwpożarowej - Państwowy Instytut Badawczy \\ *Corresponding author / Autor korespondencyjny: mwyszomirska@cnbop.pl
}

\title{
Tax and Legal Issues Related to the Implementation of Research and Development Projects in the Area of "Security and Defense"
}

\section{Kwestie podatkowoprawne związane z realizacją projektów badawczo-rozwojowych w obszarze „Bezpieczeństwo i Obronność"}

\begin{abstract}
Purpose: The aim of the article is to discuss tax issues related to the settlement of subsidies for the implementation of projects in the area of "Security and Defense". The grant beneficiaries face numerous problems with the interpretation of the provisions of the VAT Act, which may result in serious financial consequences in the event of incorrect application of the VAT Act. This publication analyses and indicates solutions to these problems, which are most often raised by consortia, both in applications for tax interpretations and in complaints to administrative courts of both instances.

Introduction: Among the important forms of activity for the security and defence of the state, a special role is played by scientific and research and development projects, which not only increase the potential of scientific and industrial entities, but also create Polish know-how in the field of critical technologies in the area of "Security and defence". The implementation of projects financed from the state budget places on the beneficiaries the obligation of a "regime" method of settling public funds, both by applying the provisions on public procurement, constructing civil contracts, taking into account the fact that funds from subsidies are available, as well as performing special diligence in tax settlements with the tax authorities.

Methodology: The theoretical research methods were used in the work, including the analysis of literature, judgments of common courts and the Provincial and Supreme Administrative Court, as well as tax interpretations issued by the Director of the National Revenue Administration. The publication also provides an interpretation of national regulations as well as directives and case law of the Court of Justice of the European Union.

Conclusions: Tax law is the branch of law that arouses the greatest emotions and controversy. It affects all of us, and in the event of incorrect application of the rules - it has serious financial consequences. Members of consortia implementing projects financed by the The National Centre for Research and Development (NCBR) also remain taxpayers, to whom the author of the article proposed the interpretation of the provisions of the VAT Act and discussed national and EU jurisprudence in order to facilitate the correct implementation of tax obligations by the consortia.

Keywords: VAT taxation of subsidies, eligibility of expenses, right to deduct input tax, transfer of proprietary copyrights to the State Treasury, commercialization of results of scientific research and development works
\end{abstract}

Type of article: review article

Received: 25.10.2021; Reviewed: 07.11.2021; Accepted: 08.11.2021;

Author's ORCID ID: M. Wyszomirska - 0000-0002-7780-2699

Please cite as: SFT Vol. 58 Issue 2, 2021, pp. 22-36, https://doi.org/10.12845/sft.58.2.2021.2;

This is an open access article under the CC BY-SA 4.0 license (https://creativecommons.org/licenses/by-sa/4.0/).

\section{ABSTRAKT}

Cel: Celem artykułu jest omówienie kwestii podatkowych związanych z rozliczeniem dotacji na realizację projektów w obszarze „Bezpieczeństwo i Obronność". Beneficjenci dotacji napotykają bowiem na liczne problemy z interpretacją przepisów ustawy o podatku od towarów i usług, co może skutkować poważnymi konsekwencjami finansowymi w przypadku niewłaściwego zastosowania ustawy VAT. Niniejsza publikacja analizuje i wskazuje rozwiązania tych problemów, które są najczęściej podnoszone przez konsorcja zarówno we wnioskach o wydanie interpretacji podatkowych, jak i w skargach do sądów administracyjnych obu instancji.

Wprowadzenie: Wśród istotnych form działalności na rzecz bezpieczeństwa i obronności państwa szczególną role odgrywaja projekty naukowe i badawczo-rozwojowe, które nie tylko zwiększają potencjał podmiotów naukowych i przemysłowych, ale tworzą również polskie know-how w zakresie krytycznych technologii w obszarze „Bezpieczeństwo i obronność”. Realizacja projektów finansowanych ze środków budżetu państwa nakłada na beneficjentów obowiązek ściśle określonego sposobu rozliczania środków publicznych, zarówno przez stosowanie przepisów dotyczących zamówień publicznych, konstruowania zawieranych umów cywilnych z uwzględnieniem faktu dysponowania środkami z dotacji, jak też dopełnienia szczególnej staranności w rozliczeniach podatkowych z aparatem skarbowym. 
Metodologia: W pracy wykorzystano teoretyczne metody badawcze, w tym analizę literatury, wyroków sądów powszechnych oraz sądów wojewódzkich i Naczelnego Sądu Administracyjnego, jak również interpretacje podatkowe wydane przez Dyrektora Krajowej Administracji Skarbowej. W publikacji dokonano również wykładni przepisów krajowych oraz dyrektyw i orzecznictwa Trybunału Sprawiedliwości Unii Europejskiej.

Wnioski: Prawo podatkowe to gałąź prawa, która wzbudza największe emocje i kontrowersje. Dotyka bowiem nas wszystkich, zaś w przypadku nieprawidłowego zastosowania przepisów - wywołuje poważne skutki finansowe. Członkowie konsorcjów realizujących projekty finansowane ze środków Narodowego Centrum Badań i Rozwoju (NCBR) pozostają również podatnikami, którym autorka artykułu zaproponowała wykładnie przepisów ustawy VAT oraz omówiła orzecznictwo krajowe i unijne, aby ułatwić konsorcjom prawidłową realizację obowiązków podatkowych.

Słowa kluczowe: opodatkowanie VAT dotacji, kwalifikowalność wydatków, prawo do odliczenia podatku naliczonego, przeniesienie autorskich praw majątkowych na Skarb Państwa, komercjalizacja wyników badań naukowych i prac rozwojowych

Typ artykułu: artykuł przeglądowy

Przyjęty: 25.10.2021; Zrecenzowany: 07.11.2021; Zaakceptowany: 08.11.2021;

Identyfikatory ORCID autora: M. Wyszomirska - 0000-0002-7780-2699

Proszę cytować: SFT Vol. 58 Issue 2, 2021, pp. 22-36, https://doi.org/10.12845/sft.58.2.2021.2;

Artykuł udostępniany na licencji CC BY-SA 4.0 (https://creativecommons.org/licenses/by-sa/4.0/).

\section{Introduction}

In recent years, tax aspects of granting subsidies for the implementation of projects financed from the state budget have become the subject of many court disputes with tax authorities, numerous applications for individual interpretations, and even an application from the Minister of the Interior and Administration to the Minister of Finance for a general interpretation regarding tax liabilities resulting from the implementation of projects for security and defence, financed under the resources of the National Centre for Research and Development [1].

Tax obligations are an element of public life that affects the general public. We all deal with tax law, because everyone has to pay tribute to the state budget - regardless of the legal status and type of activities subject to taxation. Our duties towards the tax authorities activate the entire tax machine, and we become participants in the application of the law. This article is an attempt to introduce and discuss tax issues related to the settlement of subsidies for the implementation of projects in the area of "Security and Defence", by discussing both tax regulations and interpretations, and the jurisprudence of administrative courts.

\section{Legal nature of a consortium as a party to agreements with the National Centre for Research and Development}

In the light of the case law of common courts (see the verdict of the Court of Appeal in Warsaw of 4 March 2016, VI ACa 83/16; the verdict of the Supreme Court of 10 September 2015, II CSK 630/14; the verdict of the Court of Appeal in Szczecin of of 7 March 2013, I ACa 718/12) [2-4]) a consortium is a contractual relationship between the parties to the agreement. As part of this relationship, each of the consortium members undertakes to undertake specific activities for the benefit of the

\section{Wprowadzenie}

Aspekty podatkowe towarzyszące udzielaniu dotacji na realizację projektów finansowanych z budżetu państwa stały się w ostatnich latach przedmiotem wielu sporów sądowych z organami podatkowymi, licznych wniosków o wydanie interpretacji indywidualnych, a nawet wystąpienia Ministra Spraw Wewnętrznych i Administracji do Ministra Finansów o wydanie interpretacji ogólnej w zakresie zobowiązań podatkowych wynikających z realizacji projektów na rzecz bezpieczeństwa i obronności, finansowanych w ramach środków Narodowego Centrum Badań i Rozwoju [1].

Obowiązki podatkowe to ta część życia publicznego, która dotyka ogół społeczeństwa. Z prawem podatkowym mamy do czynienia wszyscy, gdyż każdy musi płacić daninę na rzecz budżetu państwa - niezależnie od statusu prawnego oraz rodzaju czynności podlegających opodatkowaniu. Nasze obowiązki względem fiskusa uruchamiają całą machinę podatkową, a my stajemy się uczestnikami stosowania prawa. Niniejsza publikacja stanowi próbę przybliżenia i omówienia kwestii podatkowych związanych z rozliczeniem dotacji na realizację projektów w obszarze „Bezpieczeństwo i Obronność”, przez omówienie zarówno przepisów i interpretacji podatkowych, jak i orzecznictwa sądów administracyjnych.

\section{Charakter prawny konsorcjum jako strony umów zawieranych z Narodowym Centrum Badań i Rozwoju}

W świetle orzecznictwa sądów powszechnych (zob. wyrok Sądu Apelacyjnego w Warszawie z dnia 4 marca 2016 r., VI ACa 83/16; wyrok Sądu Najwyższego z dnia 10 września 2015 r., II CSK 630/14; wyrok Sądu Apelacyjnego w Szczecinie z dnia 7 marca 2013 r., I ACa 718/12) [2-4]) konsorcjum jest stosunkiem zobowiązaniowym łączącym strony umowy. W ramach tej więzi obligacyjnej każdy z konsorcjantów zobowiązuje się do określonego działania na rzecz konsorcjum dla osiągnięcia wspólnego 
consortium in order to achieve a common economic goal. The search for the meaning of the term 'consortium' in the jurisprudence results from the fact that the consortium agreement is not regulated in the civil code. Also, there is no legal definition of a consortium in any other civil or tax regulations, therefore it can be assumed that concluding this type of agreement is based on freedom of contract (art. 3531 of the civil code). The essential fact remains that the consortium does not have legal personality. Only members of the consortium have the legal capacity and capacity to perform acts in law, and by concluding the agreement, they can shape it in any way, as long as its content or purpose does not contradict the act, the principles of social coexistence and the properties of such a relationship. When concluding a consortium agreement, entities may specify who will externally represent the consortium (it may also be a third party). As a rule, syndicates do not have common property (although they may have joint bank accounts), and all forms of payment are regulated by the designated leader or representative of the consortium.

When transferring the above considerations to the basis of this publication, it should be noted that scientific consortia undertaking joint ventures in the field of scientific research and development, like other consortia, do not have legal personality and therefore cannot be considered a taxpayer of value added tax.

According to art. $15 \mathrm{sec} .1$ of the Act of 11 March 2004 on tax on goods and services (i.e. Polish Journal of Laws: Dz.U. 2021 r., poz. 685 , as amended) [5], taxpayers are legal persons, organizational units without legal personality and physical persons, independently carrying out economic activity, referred to in paragraph 2, regardless of the purpose or result of such activity. Within the meaning of art. $15 \mathrm{sec}$. 2, economic activities include any activities of the manufacturers, traders or service providers, including natural resource extractors and farmers, as well as the activities of freelancers. Economic activity also includes activities consisting in the use of goods or intangible assets on a continuous basis for commercial purposes.

The Polish legislator, being a member of the European Union, did not use the option provided for in art. 11 of the Council Directive 2006/112/EC of 28 November 2006 on the common system of value added tax (Official Journal of the European Union No. 347, p. 1, as amended) [6] and on the basis of national tax law did not establish the consortium as a taxable person for VAT. Therefore, partners operating within a consortium and implementing the contract concluded with NCBR remain separate VAT taxpayers - obliged to apply the general principles regulated in the VAT Act and in the executive acts. In addition, it should be mentioned that consortium members may, of course, assume in the agreement that the legal issues concerning, inter alia, signing contracts, financial settlements or issuing invoices for the work performed by the consortium participants will be the responsibility of the consortium member appointed by the other consortium members, nevertheless each of the consortium members will still be a separate VAT payer. celu gospodarczego. Poszukiwanie w orzecznictwie znaczenia pojęcia konsorcjum wynika $z$ faktu, że umowa konsorcjum nie została uregulowana w kodeksie cywilnym. Również w żadnych innych przepisach cywilnych czy też podatkowych nie ma legalnej definicji konsorcjum, dlatego też można przyjąć, że zawieranie tego typu umowy ma swoje źródło $w$ zasadzie swobody umów (art. 3531 k.c.). Istotny pozostaje fakt, że konsorcjum nie posiada osobowości prawnej. Zdolność prawną i zdolność do czynności prawnych posiadają wyłącznie członkowie konsorcjum, którzy zawierając umowę mogą ją ukształtować w sposób dowolny, byleby jej treść lub cel nie sprzeciwiały się ustawie, zasadom współżycia społecznego oraz właściwości takiego stosunku. Zawierając umowę konsorcjum podmioty mogą określić, kto będzie reprezentował konsorcjum na zewnątrz (może to być także osoba trzecia). Co do zasady, konsorcja nie mają też wspólnego majątku (chociaż mogą mieć wspólne rachunki bankowe), a wszelkie formy płatności regulowane są przez wyznaczonego lidera lub osobę reprezentującą konsorcjum.

Przenosząc powyższe rozważania na grunt niniejszej publikacji należy wskazać, że konsorcja naukowe podejmujące wspólne przedsięwzięcie w zakresie badań naukowych oraz prac badawczo-rozwojowych, podobnie jak inne konsorcja, nie posiadają osobowości prawnej i tym samym nie mogą zostać uznane za podatnika podatku od towarów i usług.

Zgodnie bowiem z art. 15 ust. 1 ustawy z dnia 11 marca 2004 r. o podatku od towarów i usług (tj. Dz.U. z 2021 r., poz. 685 ze zm.) [5] podatnikami są osoby prawne, jednostki organizacyjne niemające osobowości prawnej oraz osoby fizyczne, wykonujące samodzielnie działalność gospodarczą, o której mowa w ust. 2, bez względu na cel lub rezultat takiej działalności. W rozumieniu art. 15 ust. 2 działalność gospodarcza obejmuje wszelką działalność producentów, handlowców lub usługodawców, w tym podmiotów pozyskujących zasoby naturalne oraz rolników, a także działalność osób wykonujących wolne zawody. Działalność gospodarcza to również czynności polegające na wykorzystywaniu towarów lub wartości niematerialnych i prawnych w sposób ciągły dla celów zarobkowych.

Polski ustawodawca, będąc członkiem Unii Europejskiej, nie skorzystał jednak z możliwości przewidzianej w art. 11 dyrektywy Rady 2006/112/WE z dnia 28 listopada 2006 r. w sprawie wspólnego systemu podatku od wartości dodanej (Dz.Urz.UE.L $\mathrm{Nr} 347$, s. 1, z późn. zm.) [6] i na gruncie krajowego prawa podatkowego nie ustanowił konsorcjum jako podatnika podatku VAT. W związku z powyższym partnerzy działający w ramach konsorcjum i realizujący umowę zawartą z NCBR nadal pozostają odrębnymi podatnikami VAT - zobowiązanymi do stosowania ogólnych zasad uregulowanych w ustawie o podatku od towarów i usług oraz w aktach wykonawczych. Ponadto należy wspomnieć, że w umowie konsorcjanci mogą oczywiście przyjąć, że kwestiami prawnymi dotyczącymi m.in. podpisywania umów, rozliczeniami finansowymi czy też wystawianiem faktur za prace wykonane przez uczestników konsorcjum będzie zajmował się członek konsorcjum wyznaczony przez konsorcjantów, nie mniej jednak nadal każdy z członków konsorcjum będzie odrębnym podatnikiem VAT. 


\section{General outline of financing research and development works in the area of "Security and Defence"}

The process of financing scientific research and development works carried out within consortia established by research institutes, entrepreneurs and scientific institutions is part of the national defence and security strategy. The intermediary between the consortia and the State Treasury - the recipient of the results of research and development works is the National Centre for Research and Development. The basis for the Centre's operation is the Act of 30 April 2010 on the National Centre for Research and Development (i.e. Polish Journal of Laws: Dz.U. z 2020 r., poz. 1861) [7], according to which NCBR is an executive agency within the meaning of the Public Finance Act, established to carry out tasks in the field of science, technology and innovation policy of the state. The Centre is a party to financing/co-financing agreements concluded with the leader and members of a consortium. Each of the agreements specifies in particular the subject of the agreement, the rights and obligations of the parties, the value and conditions and form of financing, cost eligibility, control and storage of documents, the procedure and conditions for terminating the agreement and suspending the grant, reasons for returning the grant or property liability for the project implementation. When listing the essential provisions of the contract, one cannot forget about intellectual property rights, which have been specifically regulated in the contract for financing a research or development project in the area of "Security and Defence". As it results from the general template of the agreement with NCBR, in the case of financing this type of project, the Centre may, within twelve months from the date of completing the project, submit to the entity to which the director has granted funds a written statement on the use of a work or invention, utility model or an industrial design resulting from the implementation of this project. In this case, the State Treasury is entitled to use the work free of charge in the fields of exploitation listed in the submitted statement, selected from among all known at the end of the project or invention, utility model or industrial design on the basis of a full, non-exclusive license, unlimited in terms of territory and time, along with the right to make any changes, adaptations, alterations and modifications as well as the right to grant sub-licenses. The State Treasury is represented in these matters by the entity indicated in the agreement for the execution and financing of the project, and in the absence of such indication - by the Minister of National Defence.

\section{Subsidies for the implementation of research and development projects and VAT}

Until the end of 2015, applicants (consortium members) implementing projects from the NCBR funds did not deduct VAT on purchases of goods and services used to perform the tasks, showing the deductible tax as eligible costs. Such line of conduct was based on the interpretation of art. $86 \mathrm{sec} .1$ and art. 29a of the VAT Act, as well as tax interpretations, which until the end

\section{Ogólny zarys finansowania badań naukowych i prac rozwojowych w obszarze „Bezpieczeń- stwo i Obronność"}

W strategię obronności i bezpieczeństwa państwa wpisuje się proces finansowania badań naukowych i prac rozwojowych, prowadzonych w ramach konsorcjów powołanych przez instytuty badawcze, przedsiębiorców oraz placówki naukowe. Pomiotem pośredniczącym pomiędzy konsorcjami i Skarbem Państwa - odbiorcą efektów badań naukowych i prac rozwojowych pozostaje Narodowe Centrum Badań i Rozwoju. Podstawą działania Centrum jest ustawa z dnia 30 kwietnia 2010 r. o Narodowym Centrum Badań i Rozwoju (tj. Dz.U. z 2020 r., poz. 1861) [7], zgodnie z którą NCBR jest agencją wykonawczą w rozumieniu ustawy o finansach publicznych, powołaną do realizacji zadań z zakresu polityki naukowej, naukowo-technicznej i innowacyjnej państwa. Centrum jest stroną umów o finansowanie/dofinansowanie, zawieranych z liderem i członkami konsorcjum. Każda z umów określa w szczególności przedmiot umowy, prawa i obowiązki stron, wartość oraz warunki i formę finansowania, kwalifikowalność kosztów, kontrolę i przechowywanie dokumentów, tryb i warunki rozwiązania umowy oraz wstrzymania dofinansowania, przyczyny zwrotu dofinansowania czy też odpowiedzialność majątkową za realizację projektu. Wymieniając zasadnicze postanowienia umowy nie można zapomnieć o prawach własności intelektualnej, które zostały w szczególny sposób uregulowane w umowie o finansowanie projektu dotyczącego badań naukowych lub prac rozwojowych w obszarze „Obronność i bezpieczeństwo". Jak wynika z ogólnego wzoru umowy z NCBR, w przypadku finansowania tego rodzaju projektu, Centrum może w terminie do dwunastu miesięcy od dnia zakończenia realizacji projektu, złożyć podmiotowi, któremu dyrektor przyznał środki finansowe, pisemne oświadczenie o korzystaniu z utworu lub z wynalazku, wzoru użytkowego lub wzoru przemysłowego powstałego $w$ wyniku realizacji tego projektu. W takim przypadku Skarb Państwa uprawniony jest do nieodpłatnego korzystania z utworu na polach eksploatacji wymienionych w złożonym oświadczeniu, wybranych spośród wszystkich znanych na dzień zakończenia projektu lub z wynalazku, wzoru użytkowego lub wzoru przemysłowego na zasadzie licencji pełnej, niewyłącznej, nieograniczonej terytorialnie i czasowo, wraz z prawem do dokonywania dowolnych zmian, adaptacji, przeróbek i modyfikacji oraz prawem do udzielania sublicencji. Skarb Państwa reprezentowany jest w tych sprawach przez podmiot wskazany w umowie o wykonanie i finansowanie projektu, a przy braku takiego wskazania - Ministra Obrony Narodowej.

\section{Dotacje na realizacje projektów badawczo- -rozwojowych a VAT}

Do końca 2015 roku wnioskodawcy (konsorcjanci) realizujący projekty ze środków NCBR nie odliczali podatku VAT od zakupów towarów i usług wykorzystywanych do wykonania zadań, wykazując jako koszty kwalifikowane wartość podatku podlegającego odliczeniu. Taka linia postępowania opierała się na wykładni art. 86 ust. 1 oraz art. 29a ustawy o VAT, jak również interpretacjach 
of 2015 did not qualify the NCBR subsidy as subject to tax on goods and services. NCBR's financing of research and development projects and all issues related to the settlement of tasks carried out by scientific consortia did not arouse tax controversy until the first tax interpretations and judgments of administrative courts were issued in 2016, which caused a revolution in the assessment of the effects that the agreement concluded with NCBR had on the basis of VAT.

And so, in the tax ruling of 11 February 2016, No. ITPP2/4512-1086/15EK, unfavourable for consortia, the tax authority formulated a dangerous thesis that, "since - as indicated in the application - conducted scientific research and development work develop the knowledge of employees $C$., their experience and skills in the fields of science and technology related to the business activity conducted by $\mathrm{C}$. (the supply of goods and services subject to VAT), and the goods and services purchased under the project implemented for the National Centre for Research and Development are on an ongoing basis or will be used in the future to perform taxable activities, then - taking into account the fact that the funds received by $C$. (through the leader) from NCBR were intended only for the implementation of the project - it should be stated that they will affect the price of goods and services that are sold/will be sold" [8].

The change in the established and uniform interpretation of the VAT taxation of subsidies transferred by NCBR forced scientific consortia to apply for tax interpretations, which then became the subject of complaints to provincial administrative courts and the Supreme Administrative Court. The change in the position of the tax authorities also triggered numerous discussions of the legal doctrine and became a contribution to this publication.

When analysing subsidies received by the consortia for the implementation of projects in the field of defence and security, it should first be pointed out that, as a rule, receiving a subsidy does not constitute an activity subject to VAT. However, the very receipt of it under strictly defined conditions may result in the need to increase the tax base by its value, as an element that has a real impact on the price of another activity (e.g. provision of services). The subsidy must be received by the taxpayer (to the bank account) and must have a direct impact on the price of the goods or services provided by the taxpayer-beneficiary. Thanks to the subsidy, the service has a price that is lower by a specific amount or equalizes the revenues from the sale of the service to the level before the discount. The subsidy increases the tax base in the net amount of the subsidy, therefore this key element of the regulation contained in art. 29a paragraph. 1 of the VAT Act requires a thorough analysis of individual agreements - taking into account the principles of granting subsidies.

Pursuant to art. $5 \mathrm{sec} .1$ point 1 of the VAT Act, VAT is subject to the paid delivery of goods and the paid provision of services within the territory of the country. By providing the services referred to in art. 5 sec. 1 point 1, it shall be understood as any service provided to a physical person, legal person or organizational unit without legal personality, which does not constitute a supply of goods within the meaning of art. 7 (article 8 (1) of the VAT Act). On the other hand, pursuant to art. 15 of the VAT Act, taxpayers of this tax are legal persons, organizational podatkowych, które do końca 2015 roku nie kwalifikowały dotacji z NCBR jako podlegającej opodatkowaniu podatkiem od towarów i usług. Finansowanie przez NCBR projektów badawczo-rozwojowych oraz wszelkie kwestie dotyczące rozliczania zadań realizowanych przez konsorcja naukowe nie wzbudzały kontrowersji podatkowych aż do wydania w 2016 roku pierwszych interpretacji podatkowych oraz wyroków sądów administracyjnych, które wywołały rewolucję w ocenie skutków, jakie umowy zawarte z NCBR niosły za sobą na gruncie podatku VAT.

I tak, w niekorzystnej dla konsorcjów interpretacji indywidualnej z dnia 11 lutego 2016 r. nr ITPP2/4512-1086/15EK organ podatkowy sformułował niebezpieczną tezę, że „skoro - jak wskazano we wniosku - prowadzone badania naukowe i prace rozwojowe rozwijają wiedzę pracowników C., ich doświadczenie i umiejętności w zakresie dziedzin nauki i technologii związanych z prowadzoną przez C. działalnością gospodarczą (dostawą towarów i świadczeniem usług opodatkowanych podatkiem od towarów i usług), a towary i usługi nabywane w ramach projektu realizowanego na rzecz Narodowego Centrum Badań i Rozwoju są na bieżąco lub będą w przyszłości wykorzystywane do wykonywania czynności opodatkowanych, to - przy uwzględnieniu faktu, że środki finansowe otrzymane przez C. (za pośrednictwem lidera) z NCBR przeznaczone były wyłącznie na realizację projektu - należy stwierdzić, że będą one miały wpływ na cenę towarów i usług, które sprzedaje/będzie sprzedawało. Zatem ww. środki należy uznać za dopłatę, która ma/będzie miała bezpośredni wpływ na cenę dostaw dokonywanych/które będą dokonywane przez C. na rzecz osób trzecich, a więc za taką, która podlega opodatkowaniu podatkiem od towarów i usług" [8].

Zmiana ukształtowanej i dotychczas jednolitej wykładni w zakresie opodatkowania podatkiem VAT dotacji przekazywanych przez NCBR zmusiła konsorcja naukowe do występowania o interpretacje podatkowe, które stały się następnie przedmiotem skarg do wojewódzkich sądów administracyjnych oraz do Naczelnego Sądu Administracyjnego. Zmiana stanowiska organów podatkowych wywołała również liczne dyskusje doktryny prawa i stała się także przyczynkiem do niniejszej publikacji.

Dokonując analizy dotacji otrzymywanych przez konsorcja na realizację projektów w obszarze obronności i bezpieczeństwa w pierwszej kolejności należy wskazać, że co do zasady otrzymanie dotacji nie stanowi czynności opodatkowanej podatkiem VAT. Jednakże samo jej otrzymanie w ściśle określonych warunkach może skutkować koniecznością zwiększenia o jej wartość podstawy opodatkowania, jako elementu realnie wpływającego na cenę innej czynności (np. świadczenie usług). Dotacja musi zostać przez podatnika otrzymana (na rachunek bankowy) i musi mieć bezpośredni wpływ na cenę towarów lub usług świadczonych przez podatnika-beneficjenta. Dzięki dotacji usługa ma cenę niższą o konkretną kwotę lub wyrównuje przychody ze sprzedaży usługi do poziomu sprzed obniżki. Dotacja zwiększa podstawę opodatkowania w kwocie netto dotacji, dlatego też ten kluczowy element regulacji zawartej w art. 29a ust. 1 ustawy o VAT wymaga wnikliwej analizy poszczególnych umów - z uwzględnieniem zasad przyznania dotacji.

Zgodnie $z$ art. 5 ust. 1 pkt 1 ustawy o VAT opodatkowaniu podatkiem od towarów i usług podlega odpłatna dostawa towarów i odpłatne świadczenie usług na terytorium kraju. Przez 
units without legal personality and physical persons who independently carry out economic activity defined in the Act, regardless of the purpose or result of such activity. As indicated above, due to the fact that the Polish legislator did not establish the consortium as a VAT taxpayer, members of the consortium implementing the contract with NCBR remain separate taxpayers of this tax and settle their accounts in accordance with the general rules of the VAT Act. It should be reminded here that taxation with tax on goods and services - in accordance with the principle of universality of taxation - applies to all transactions involving the supply of goods or services, provided that they are carried out by taxpayers within the meaning of the Act and are performed as part of the economic activity. Moreover, art. 29a par. 1 of the VAT Act states that the tax base, subject to paragraph $2-5$, art. $30 \mathrm{a}-30 \mathrm{c}$, art. 32 , art. 119 and art. $120 \mathrm{sec} .4$ and 5 , is everything that is the payment that the supplier of the goods or the service provider has received or is to receive for the sale from the buyer, recipient or third party, including received subsidies, subventions and other payments of a similar nature having a direct impact on the price of the goods or services provided by the taxpayer. At this point, it is worth recalling the verdict of the Provincial Administrative Court of 5 January 2017 (I SA/Wr 1120/16), where the Court will state that "part of the payment for the delivery or performance of a service also includes subsidies, subventions and other surcharges of a similar nature received by the taxpayer, having a direct impact on the price (amount payable) of the goods or services provided by the taxpayer, which is indicated by the use of the term "including". However, it should be emphasized that receiving a subsidy is not a separate taxable activity. The subsidy is taxable as a component of the price of the activity to which the subsidy is related. Therefore, on the basis of art. 29a par. 1 of the VAT Act, it cannot be considered that the subsidy is taxed as an activity (...). This means that it is important for the taxation of subsidies to recognize the direct impact of the subsidy on the price of the service or supply provided by the recipient of the subsidy. This means that for the taxation of a subsidy as part of the price for a service or supply, it is necessary to establish a direct impact of the subsidy on the price of the service or supply" [9]. The provision mentioned above reflects art. 73 of directive 2006/112. Pursuant to art. 73 of the directive, with regard to the supply of goods and the provision of services other than those referred to in art. 74-77, the taxable amount covers everything which is payment received or which the supplier or service provider will receive in return for a supply of goods or services from a buyer, recipient or third party, including subsidies directly related to the price of such supply or service. Therefore, in order to determine whether or not given subsidies are taxed with value added tax, the specific conditions of their awarding, defining the objectives of the subsidy implemented in a specific form, remain relevant. From the content of the provisions mentioned above, one can therefore formulate a thesis that if, in connection with a specific supply of goods or services, the taxpayer receives a subsidy (subventions) constituting an additional payment to the price of a good or service - this type of subsidy constitutes, in addition to the price, a supplementary element of the tax base for a given delivery or service. Spending a subsidy in order to świadczenie usług, o którym mowa $w$ art. 5 ust. 1 pkt 1, rozumie się każde świadczenie na rzecz osoby fizycznej, osoby prawnej lub jednostki organizacyjnej niemającej osobowości prawnej, które nie stanowi dostawy towarów w rozumieniu art. 7 (art. 8 ust. 1 ustawy o VAT). Z kolei w myśl art. 15 ustawy o VAT podatnikami tego podatku są osoby prawne, jednostki organizacyjne niemające osobowości prawnej oraz osoby fizyczne, wykonujące samodzielnie działalność gospodarczą zdefiniowaną w ustawie, bez względu na cel lub rezultat takiej działalności. W związku z tym, że jak wskazano wcześniej, krajowy ustawodawca nie ustanowił konsorcjum jako podatnika podatku VAT, członkowie konsorcjum realizujący umowę z NCBR pozostają odrębnymi podatnikami tego podatku i rozliczają się zgodnie z ogólnymi regułami ustawy o VAT. Przypomnijmy również, że opodatkowaniu podatkiem od towarów i usług - zgodnie z zasadą powszechności opodatkowania - podlegają wszelkie transakcje, których przedmiotem jest dostawa towarów lub świadczenie usług, pod warunkiem, że są one realizowane przez podatników w rozumieniu ustawy i są wykonywane $w$ ramach działalności gospodarczej. Ponadto $z$ art. 29a ust. 1 ustawy o VAT wynika, że podstawą opodatkowania, z zastrzeżeniem ust. 2-5, art. 30a-30c, art. 32, art. 119 oraz art. 120 ust. 4 i 5 , jest wszystko, co stanowi zapłatę, którą dokonujący dostawy towarów lub usługodawca otrzymał lub ma otrzymać z tytułu sprzedaży od nabywcy, usługobiorcy lub osoby trzeciej, włącznie z otrzymanymi dotacjami, subwencjami i innymi dopłatami o podobnym charakterze mającymi bezpośredni wpływ na cenę towarów dostarczanych lub usług świadczonych przez podatnika. W tym miejscu warto przywołać wyrok Wojewódzkiego Sądu Administracyjnego (WSA) z dnia 5 stycznia 2017 r. (I SA/Wr 1120/16), w którym Sąd stwierdzi, że „za część zapłaty za dostawę lub wykonanie usługi uznaje się także otrzymane przez podatnika dotacje, subwencje i inne dopłaty o podobnym charakterze, mające bezpośredni wpływ na cenę (kwotę należną) towarów dostarczanych lub usług świadczonych przez podatnika, wskazuje na to użycie sformułowania "włącznie z". Należy jednak podkreślić, że otrzymanie dotacji nie jest odrębną czynnością opodatkowaną. Dotacja podlega opodatkowaniu jako składnik ceny czynności, z którą dotacja jest związana. Nie można zatem przyjąć, na podstawie art. 29a ust. 1 ustawy o VAT, że dotacja jako czynność jest opodatkowana. (...) Oznacza to, że istotne znaczenie dla opodatkowania dotacji ma stwierdzenie bezpośredniego wpływy dotacji na cenę świadczonej usługi lub dostawy przez otrzymującego dotację. Zatem do opodatkowania dotacji jako elementu ceny za usługę lub dostawę konieczne jest stwierdzenie bezpośredniego wpływu dotacji na cenę usługi lub dostawy" [9].

Przywołany wyżej przepis stanowi odzwierciedlenie art. 73 dyrektywy 2006/112. W myśl art. 73 dyrektywy, w odniesieniu do dostaw towarów i świadczenia usług innych niż te, o których mowa w art. 74-77, podstawa opodatkowania obejmuje wszystko, co stanowi zapłatę otrzymaną lub którą dostawca lub usługodawca otrzyma w zamian za dostawę towarów lub świadczenie usług, od nabywcy, usługobiorcy lub osoby trzeciej, włącznie z subwencjami związanymi bezpośrednio z ceną takiej dostawy lub świadczenia. A zatem dla określenia, czy dane dotacje są czy nie są opodatkowane podatkiem od towarów i usług istotne pozostają szczegółowe warunki ich przyznawania, określające cele dofinansowania realizowanego w określonej formie. 
finance a specific activity subject to tax on goods and services tax is the criterion for recognizing the subsidy as increasing turnover. However, those subsidies that cannot be related to specific activities subject to VAT do not constitute turnover within the meaning of art. 29a par. 1 of the VAT Act, i.e. they do not increase the tax base with this tax.

The latest jurisprudence of administrative courts presents a similar position. In the verdict of the Supreme Administrative Court of 31 July 2020 (I FSK 1792/17), it is stated that "the criterion for recognizing a subsidy as increasing turnover is the statement that the subsidy is made in order to finance a specific activity subject to tax on goods and services. Only the subsidies in question in relation to the selling price (at the supplier of the goods or services) are subject to taxation. However, the subsidies in question are not subject to taxation up to the purchase price (at the purchaser of the goods or services)" [10]. In another ruling of the Supreme Administrative Court of 21 March 2019 (I FSK 1363/18), the court found that “(...) the funding provided by the National Centre for Research and Development is intended to finance development and scientific research carried out by the leader for defence and research of the state. Thus, the co-financing covers the related costs. It does not constitute a subsidy, subvention or other similar surcharge directly affecting the price of goods or services provided by the taxpayer" [11].

Therefore, bearing in mind the provisions of the Value Added Tax Act and the case law of the Provincial Administrative Court and the Supreme Administrative Court mentioned above, it should be concluded that the VAT tax base is increased only by such subsidies that are absolutely and directly related to a given supply of goods or services. If there is no such direct relationship, the general subsidy to cover operating costs or the costs of implementing a specific task does not increase the tax base, and thus is not subject to taxation. Also, the jurisprudence of CJEU shows that determining the relationship between a subsidy and the provision of services or the supply of goods as "direct" is important for taxation. In the justification of the verdict of 22 November 2001 in the case C-184/00 Office des Produits Wallons ASBL v. Belgian State (ECR 2001/11B/I-9115) [12], it was emphasized that the mere fact that the subsidy (or other method of co-financing) influences the final price of the service (which is almost always the case), it cannot be decisive for considering that the subsidy should increase the tax base. At the same time, it was clarified that in order to recognize a subsidy (subventions, etc.) as increasing the tax base, it is necessary to state that the subsidy is made in order to finance a specific taxable activity (supply of goods or services). Thus, it was in favour of such an understanding of the provisions that the taxation of subsidies would only apply to those subsidies that correspond to all or part of the remuneration for such activity. The subsidy should also be related to a specific, designated supply or service. Therefore, there is no doubt that subsidies intended to cover the costs of operating or carrying out a specific task - although they may ultimately have some effect on the price of the supplied services or goods - are not included in the tax base.
Z treści cytowanych wyżej przepisów można zatem sformułować tezę, że jeżeli w związku z konkretną dostawą towarów lub świadczeniem usług podatnik otrzymuje dofinansowanie (dotacje, subwencje) będące dopłatą do ceny towaru lub usługi - tego rodzaju dofinansowanie stanowi, obok ceny, uzupełniający element podstawy opodatkowania z tytułu danej dostawy lub świadczenia. Wydatkowanie dotacji w celu sfinansowania konkretnej czynności podlegającej opodatkowaniu podatkiem od towarów i usług jest kryterium uznania dotacji za zwiększającą obrót. Natomiast te dotacje, które nie dają się powiązać z konkretnymi czynnościami podlegającymi opodatkowaniu podatkiem VAT nie stanowią obrotu w rozumieniu przepisu art. 29a ust. 1 ustawy o VAT, czyli nie zwiększają podstawy opodatkowania tym podatkiem.

Podobne stanowisko prezentuje najnowsze orzecznictwo sądów administracyjnych. W wyroku Naczelnego Sądu Administracyjnego (NSA) z dnia 31 lipca 2020 r. (I FSK 1792/17) czytamy, że „kryterium uznania dotacji za zwiększającą obrót stanowi stwierdzenie, że dotacja dokonywana jest w celu sfinansowania konkretnej czynności podlegającej opodatkowaniu podatkiem od towarów i usług. Opodatkowaniu podlegają bowiem jedynie przedmiotowe dotacje do ceny sprzedaży (u dostawcy towaru lub usługi). Nie podlegają natomiast opodatkowaniu przedmiotowe dotacje do ceny zakupu (u nabywcy towaru lub usługi)" [10].

W kolejnym orzeczeniu NSA z dnia 21 marca 2019 r. (I FSK 1363/18) sąd uznał, że „(...) dofinansowanie przekazane przez NCBiR ma za zadanie sfinansować prowadzone przez lidera i członków konsorcjum prace rozwojowe i badania naukowe na rzecz obronności i bezpieczeństwa państwa. Tym samym dofinansowanie pokrywa koszty z nimi związane. Nie stanowi ono dotacji, subwencji ani innej dopłaty o podobnym charakterze mającej bezpośredni wpływ na cenę towarów dostarczanych lub usług świadczonych przez podatnika" [11].

Mając zatem na uwadze przywołane wyżej przepisy ustawy o podatku od towarów i usług oraz orzecznictwo WSA i NSA, należy uznać, że podstawę opodatkowania podatkiem VAT zwiększa się tylko o takie dotacje, które w sposób bezwzględny i bezpośredni są związane z daną dostawą towarów lub świadczeniem usług. Jeżeli taki bezpośredni związek nie występuje, dofinansowanie ogólne na pokrycie kosztów działalności czy też kosztów realizacji konkretnego zadania nie zwiększa podstawy opodatkowania, a tym samym nie podlega opodatkowaniu. Również z orzecznictwa TSUE wynika, że określenie związku pomiędzy dotacją a świadczeniem usług czy dostawą towaru jako „bezpośredniego" ma istotne znaczenie dla opodatkowania. W uzasadnieniu wyroku z dnia 22 listopada 2001 r. w sprawie C-184/00 Office des Produits Wallons ASBL v. Belgian State (ECR 2001/11B/l-9115) [12] podkreślono, że sam tylko fakt, że dotacja (czy inny sposób dofinansowania) wpływa na ostateczną cenę świadczenia (co niemal zawsze ma miejsce), nie może być decydujący dla uznania, że dotacja ta powinna zwiększać podstawę opodatkowania. Jednocześnie wyjaśniono, że do uznania dotacji (subwencji itp.) za zwiększającą podstawę opodatkowania konieczne jest stwierdzenie, że dotacja ta jest dokonywana w celu sfinansowania konkretnej czynności opodatkowanej (dostawy towarów lub świadczenia usług). Tym samym opowiedziano się za takim rozumieniem przepisów, aby opodatkowanie dotacji następowało tylko w stosunku do tych dotacji, 
In the verdict of 13 June 2017 (I SA/Bd 474/17), the Provincial Administrative Court ruled that "in order for a subsidy to be directly related to the price of such supplies, it must also be paid directly to the entity in order to enable it to provide certain goods or the provision of certain services. Only in this case should the subsidy be regarded as consideration for the supply of goods or services and, consequently, be taxable. In order to determine whether a subsidy constitutes such consideration, it should be noted that the price of goods and services must, in principle, be determined no later than the time of the taxable event. It should also be noted that the obligation to pay the subsidy made by the person who grants it gives rise to a correlate, which is the beneficiary's right to receive it, because he/she made a taxable supply. This relation between the subsidy and the price must be clearly visible on the basis of an individual analysis of the circumstances underlying the payment of that remuneration" [13].

Literature indicates that subsidies always somehow affect the price of services or goods supplied by the taxpayer. However, only subsidies (funding) that are directly related to the tax base are included in the tax base. The fact that a subsidy, e.g. covering a part of the taxpayer's general costs, allowed to reduce the price of the provided services, is not a reason to include such subsidies in the tax base - if they do not apply to specific taxable activities. In practice, the subsidizing of the taxpayer's activity in some way influences the prices applied by the taxpayer. However, this fact is irrelevant to the recognition that the subsidy should increase the tax base. A similar position was presented by A. Bartosiewicz in the commentary to the VAT Act, emphasizing that in order for the received subsidy to increase the tax base, it is necessary to state that "the subsidy was made to finance the supply of specific goods or the provision of specific services" [14].

Returning to the aspect of consortium as the beneficiary of the grant obtained under the contract with NCRD, attention should be paid to the fundamental fact. The funds to cover the costs of implementing research and development projects may be allocated by the leader and individual members of the consortium only for project purposes. The main goal at the time of executing the project is usually not the commercialization of research results, although this does not exclude situations where, when joining a given project, the consortium envisages using in the future the studies acquired for the purpose of implementing the project to perform activities subject to VAT. Most often, the solutions developed in a given project are to serve the implementation of public tasks resulting from the applicable national and international legal regulations. Popularization of the project's results may take place, among others, by preparing publications in scientific journals and presenting the results at scientific, national and international conferences. In such cases, the achieved research goal will not be of a commercial nature and, therefore, the awarded subsidy will not be a subsidy to the price of the provided services, but only a reimbursement of the incurred costs (purchasing subsidy). Therefore, this form of financing the execution of the project will not constitute turnover within the meaning of art. 29a paragraph. 1 of the VAT Act and thus will not be subject to taxation, as it is not an activity listed in art. $5 \mathrm{sec}$. 1 point 1 of the act mentioned above. które odpowiadają całości lub części wynagrodzenia z tytułu takiej czynności. Dotacja powinna być związana także z konkretną, oznaczoną dostawą albo usługą. Nie ma zatem wątpliwości, że dotacje przeznaczone na pokrycie kosztów działalności lub wykonania konkretnego zadania - chociaż mogą mieć w ostatecznym rozrachunku jakiś wpływ na cenę świadczonych usług lub dostarczanych towarów - nie są uwzględniane w podstawie opodatkowania.

W wyroku z dnia 13 czerwca 2017 r. (I SA/Bd 474/17) WSA uznał, że „aby dotacja była bezpośrednio powiązana z ceną takich dostaw konieczne jest także, by była ona wypłacana danemu podmiotowi bezpośrednio w celu umożliwienia mu dostarczania określonych towarów lub świadczenia określonych usług. Jedynie w tym przypadku, dotację należy uznać za wynagrodzenie za dostawę towarów lub świadczenie usług, a w konsekwencji za podlegającą opodatkowaniu. W celu ustalenia, czy dotacja stanowi takie wynagrodzenie, należy zauważyć, że cena towarów i usług musi być, co do zasady, ustalana nie później niż w momencie zdarzenia podlegającego opodatkowaniu. Trzeba także zwrócić uwagę, iż zobowiązanie do zapłaty dotacji dokonane przez osobę, która jej udziela, rodzi korelat, jakim jest prawo beneficjenta do jej otrzymania, ponieważ dokonał on dostawy podlegającej opodatkowaniu. Ten związek pomiędzy dotacją a ceną musi być jednoznacznie widoczny na podstawie indywidualnej analizy okoliczności stanowiących podstawę wypłaty tego wynagrodzenia" [13].

W piśmiennictwie wskazuje się, że dotacje zawsze w jakiś sposób wpływają na cenę świadczonych usług czy towarów dostarczanych przez podatnika. Do podstawy opodatkowania wlicza się jednakże tylko te dotacje (dofinansowania), które są w bezpośredni sposób związane z podstawą opodatkowania. Okoliczność, że dotacja np. pokrywająca część ogólnych kosztów podatnika pozwoliła na zmniejszenie ceny świadczonych usług, nie jest powodem, aby włączać takie dotacje do podstawy opodatkowania - jeśli nie dotyczą konkretnych czynności opodatkowanych. W praktyce niemal zawsze dofinansowanie działalności podatnika wpływa w jakiś sposób na stosowane przez niego ceny. Fakt ten jednak nie ma znaczenia dla uznania czy dofinansowanie powinno zwiększyć podstawę opodatkowania. Podobne stanowisko zaprezentował A. Bartosiewicz w komentarzu do ustawy o VAT podkreślając, że aby otrzymana dotacja zwiększała podstawę opodatkowania konieczne jest stwierdzenie, że „dotacja ta została dokonana w celu sfinansowania dostawy konkretnych towarów lub świadczenia konkretnych usług" [14].

Wracając do konsorcjum jako beneficjenta dotacji uzyskanej na podstawie umowy z NCBR, należy zwrócić uwagę na zasadniczy fakt. Otóż środki finansowe na pokrycie kosztów realizacji projektów badawczo-rozwojowych, lider oraz poszczególni członkowie konsorcjum mogą przeznaczyć wyłącznie na cele projektowe. Podstawowym celem w momencie realizacji projektu nie jest zazwyczaj komercjalizacja wyników badań, choć oczywiście nie wyklucza to również takich sytuacji, kiedy przystępując do danego projektu konsorcjum przewiduje wykorzystanie w przyszłości opracowań nabytych w celu realizacji projektu do wykonywania czynności opodatkowanych podatkiem VAT. Najczęściej rozwiązania wypracowane w danym projekcie mają służyć realizacji zadań publicznych, wynikających z obowiązujących krajowych i międzynarodowych regulacji prawnych. 
When interpreting art. 29a (1) of the VAT Act, it should also be noted that the tax base includes subsidies that have a direct impact on the price of goods or services provided by the taxpayer. A direct relation of the subsidy with the price could only be considered if the price for which the consortium sells its service or goods to the buyer depended on the amount of the subsidy. The relationship between the subsidy and the price is highlighted by the Supreme Administrative Court, which in its verdict of 17 June 2009 (I FSK 571/08) [15] and in the verdict of 5 February 2015 (I FSK 821/13) [16] indicates that, where the subsidy is intended to finance costs incurred in connection with the execution of the project, it is of a purchasing nature and cannot be attributed directly to the price of the provided services, even though the recipients bear lower costs of the provided services, since each subsidy has a certain impact on the price, which does not mean that the impact is always direct. How, then, should we interpret the concept of directness? In my opinion, directness should be understood as the possibility of identifying an economic and clear relationship between the subsidy and the final value - the price of the provided service. Referring the above to the results of research, it should be concluded that the directness mentioned above will not exist, which is also confirmed by the jurisprudence of administrative courts. For instance, in the verdict of the Provincial Administrative Court in Gliwice of 21 June 2016 (III SA/GI 232/16), the court indicated, inter alia, that "the grant from NCBiR does not constitute a subsidy affecting the price within the meaning of art. 29a paragraph. 1 of the VAT Act. The grant amount covers part of the costs incurred by the contractors (the entire consortium). The grant costs reflect the proportionate share of the consortium members as a whole in the ownership of the project results" [17].

The doctrine of law also presents a similar view. As it is clear from the position of numerous commentators, subsidies from EU funds included in the VAT turnover are only those that directly affect the price of a good or service, i.e. only those whose purpose is to subsidize the sale of a given good [18]. Therefore, the regulation of art. 29a par. 1 of the VAT Act provides a basis for stating that the subsidy, surcharge, etc. received by the taxpayer will not be subject to tax on goods and services, if there is no direct link between the received subsidy and the price of a specific provided service (the possibility of allocating the subsidy in the price of the service). In the event that the method of calculating the subsidy is related to the unit price of the service only indirectly or the calculation of the subsidy is completely detached from the price of any service provided by the taxpayer, the subsidy is not taxable.

When analysing the potential problems that consortia may encounter when settling VAT, one cannot ignore the existence of exceptions to the rules set out in the Act on the Value Added Tax. From the content of art. $5 \mathrm{sec} .1$ point 1 of the VAT Act, it is clear that the supply of goods and the provision of services are, as a rule, subject to tax on goods and services only when these activities are performed for a fee. However, the legislator provided for exceptions to the above rule, which in the case of the provision of services are regulated in art. $8 \mathrm{sec}$. 2 of the VAT Act. In accordance with the act mentioned above, the following are also considered to be the provision of services against payment:
Popularyzacja efektów projektu może nastąpić m.in. przez przygotowanie publikacji w czasopismach naukowych oraz prezentację rezultatów na konferencjach naukowych, krajowych i międzynarodowych. W takich przypadkach osiągnięty cel badawczy nie będzie miał charakteru komercyjnego i co się z tym wiąże - przyznana dotacja nie będzie dopłatą do ceny świadczonych usług, ale jedynie zwrotem poniesionych kosztów (dotacja o charakterze zakupowym). Taka forma finansowania realizacji projektu nie będzie zatem stanowiła obrotu w rozumieniu art. 29a ust. 1 ustawy o VAT i tym samym nie będzie podlega opodatkowaniu, gdyż nie stanowi czynności wymienionej w art. 5 ust. 1 pkt 1 ww. ustawy.

Interpretując art. 29a ust.1 ustawy o VAT należy zaznaczyć ponadto, że podstawa opodatkowania obejmuje dotacje mające bezpośredni wpływ na cenę towarów dostarczonych lub usług świadczonych przez podatnika. 0 bezpośrednim związaniu dotacji z ceną można byłoby mówić jedynie wtedy, gdyby cena, za jaką konsorcjum sprzeda nabywcy swoją usługę lub towar, zależała od kwoty dotacji. Na związek dotacji z ceną zwraca uwagę Naczelny Sąd Administracyjny, który w wyroku z dnia 17 czerwca 2009 r. (I FSK 571/08) [15] oraz w orzeczeniu z dnia 5 lutego 2015 r. (I FSK 821/13) [16] wskazuje, że w przypadku, gdy subwencja przeznaczona jest na sfinansowanie poniesionych $w$ związku z realizacją projektu kosztów, ma ona charakter zakupowy i nie można jej przypisać bezpośredniego wpływu na cenę świadczonych usług, nawet pomimo faktu, że usługobiorcy ponoszą niższe koszty świadczonych usług, bowiem w istocie każda dotacja ma pewien wpływ na cenę, co nie znaczy, że wpływ ten zawsze jest bezpośredni. Jak zatem interpretować pojęcie bezpośredniości? Moim zdaniem przez bezpośredniość należy rozumieć możliwość zidentyfikowania ekonomicznej i wyraźnej zależności między dotacją a ostateczną wartością - ceną wykonanej usługi. Odnosząc powyższe do efektów prac badawczych należy uznać, że omawiana wyżej bezpośredniość nie zaistnieje, co potwierdza także orzecznictwo sądów administracyjnych. Dla przykładu, w wyroku WSA w Gliwicach z dnia 21 czerwca 2016 r. (III SA/GI 232/16) sąd wskazał m.in., że „dofinansowanie od NCBiR nie stanowi dotacji mającej wpływ na cenę $w$ rozumieniu art. 29a ust. 1 ustawy VAT. Kwota dofinansowania pokrywa część kosztów poniesionych przez wykonawców (całe konsorcjum). Koszty pokryte dotacją odzwierciedlają proporcjonalny udział konsorcjantów jako całości w prawach własności do wyników projektu" [17].

Podobny pogląd prezentuje również doktryna prawa. Jak wynika ze stanowiska licznych komentatorów, dotacje z funduszy unijnych zaliczane do obrotu w VAT to tylko te, które bezpośrednio wpływają na cenę towaru lub usługi, czyli tylko te, których celem jest subsydiowanie sprzedaży danego towaru [18]. Regulacja art. 29a ust. 1 ustawy VAT daje zatem podstawę do stwierdzenia, że otrzymana przez podatnika dotacja, dopłata itp. nie będzie podlegała opodatkowaniu podatkiem od towarów i usług, jeżeli brak jest elementu bezpośredniego związku otrzymywanej dotacji z ceną konkretnej, świadczonej usługi (możliwość alokacji dotacji w cenie usługi). W przypadku, kiedy sposób kalkulacji dotacji związany jest z ceną jednostkową usługi jedynie pośrednio albo kalkulacja dotacji oderwana jest całkowicie od ceny jakiejkolwiek usługi świadczonej przez podatnika, dotacja nie podlega opodatkowaniu. 
- the use of goods forming part of the taxpayer's enterprise for purposes other than the taxpayer's business activity, including, in particular, for the personal purposes of the taxpayer or its employees, including former employees, partners, shareholders, members of cooperatives and their household members, members of legal entities, members of the decision making bodies of legal persons, if the taxpayer was entitled, in whole or in part, to reduce the amount of tax due by the amount of input tax on the acquisition, import or manufacture of these goods or their component parts;

- free provision of services for the personal purposes of the taxpayer or its employees, including former employees, partners, shareholders, shareholders, members of cooperatives and their household members, members of the decision making bodies of legal persons, members of the association, and any other provision of services free of charge for purposes other than the taxpayer's business activity.

In a number of verdicts (e.g. C-498/99, LEX public No. 83900 , C-16/93, LEX public No. 83886, C- 9/81, C-154/80, publ. www. curia.europa.eu) [19] the Court of Justice of the European Union has expressed a view that the provision of services for consideration, and thus an activity subject to VAT, may be considered to be situations in which:

- there is a legal relationship between the provider and the recipient of the counter-performance;

- the remuneration received by the provider is the value actually transferred in return for the services rendered to the recipient;

- there is a direct and clearly personalized benefit on the part of the supplier of the good or service;

- payment for the received service (good or service) is directly related to the activity that would be taxed with this tax.

It seems that in the case of consortia implementing projects for security and defence and not envisaging commercialization of the results of their work, the elements mentioned above for the provision of services for remuneration cannot be perceived as typical. Going further, interpreting the provision of art. $8 \mathrm{sec}$. 2 point 2 of the VAT Act, it should be stated that in order to determine whether a specific free provision of services is subject to taxation on the basis of the Act cited above, it is important to establish the purpose of such service. If the free service will fit in with the purpose of the business activity, then the condition for recognizing such a free activity as a paid service that is subject to taxation will not be met. However, such a statement depends on the specific circumstances of a given case.
Analizując potencjalne problemy, jakie konsorcja mogą napotkać rozliczając VAT, nie można pominąć istnienia wyjątków od reguł określonych w ustawie o podatku od towarów i usług. Otóż, z treści art. 5 ust. 1 pkt 1 ustawy o VAT jednoznacznie wynika, że dostawa towarów i świadczenie usług co do zasady podlegają opodatkowaniu podatkiem od towarów i usług jedynie wówczas, gdy czynności te są wykonywane odpłatnie. Ustawodawca przewidział jednak wyjątki od powyższej reguły, które w przypadku świadczenia usług zostały uregulowane $w$ art. 8 ust. 2 ustawy o VAT. W myśl ww. przepisu, za odpłatne świadczenie usług uznaje się również:

- użycie towarów stanowiących część przedsiębiorstwa podatnika do celów innych niż działalność gospodarcza podatnika, w tym w szczególności do celów osobistych podatnika lub jego pracowników, w tym byłych pracowników, wspólników, udziałowców, akcjonariuszy, członków spółdzielni i ich domowników, członków organów stanowiących osób prawnych, członków stowarzyszenia, jeżeli podatnikowi przysługiwało, w całości lub w części, prawo do obniżenia kwoty podatku należnego o kwotę podatku naliczonego z tytułu nabycia, importu lub wytworzenia tych towarów lub ich części składowych;

- nieodpłatne świadczenie usług na cele osobiste podatnika lub jego pracowników, w tym byłych pracowników, wspólników, udziałowców, akcjonariuszy, członków spółdzielni i ich domowników, członków organów stanowiących osób prawnych, członków stowarzyszenia, oraz wszelkie inne nieodpłatne świadczenie usług do celów innych niż działalność gospodarcza podatnika.

W szeregu orzeczeń (np. C-498/99, publ. LEX nr 83900, C-16/93, publ. LEX nr 83886, C-9/81, C-154/80, publ. www.curia.europa.eu) [19] Trybunał Sprawiedliwości Unii Europejskiej wyraził pogląd, że za świadczenie usług za wynagrodzeniem, a więc czynność podlegającą opodatkowaniu VAT uważane mogą być takie sytuacje, w których:

- istnieje związek prawny między usługodawcą i usługobiorcą, w ramach którego następuje świadczenie wzajemne;

- wynagrodzenie otrzymane przez usługodawcę stanowi wartość faktycznie przekazaną w zamian za usługi świadczone na rzecz usługobiorcy;

- istnieje bezpośrednia i jasno zindywidualizowana korzyść po stronie dostawcy towaru lub usługi,

- odpłatność za otrzymane świadczenie (towar lub usługę) pozostaje w bezpośrednim związku z czynnością, która miałaby być opodatkowana tym podatkiem.

Wydaje się, że w przypadku konsorcjów realizujących projekty na rzecz bezpieczeństwa i obronności i nie przewidujących komercjalizacji wyników prac nie można dostrzec wymienionych wyżej elementów typowych dla świadczenia usług za wynagrodzeniem. Idąc dalej, interpretując przepis art. 8 ust. 2 pkt 2 ustawy o VAT, należy stwierdzić, że dla ustalenia czy konkretne nieodpłatne świadczenie usług podlega opodatkowaniu na podstawie cytowanego wyżej przepisu istotne jest ustalenie celu takiego świadczenia. Jeżeli nieodpłatne świadczenie będzie się wpisywało w cel prowadzonej działalności gospodarczej, wtedy przesłanka uznania takiej nieodpłatnej czynności za odpłatne świadczenie usług podlegające opodatkowaniu nie zostanie spełniona. Takie stwierdzenie jest jednak uzależnione od konkretnych okoliczności, występujących w danej sprawie. 


\section{Transfer of proprietary copyrights to the State Treasury}

Agreements concluded by scientific consortia with NCBR provide that if authors elements are created as a result of scientific research and development works carried out by the consortium members, then upon completion of the project, they will be transferred to the State Treasury free of charge. The transfer of rights also includes all kinds of additions to the authors elements, their modifications, details in the scope of all known and possible methods and fields of use or further transfer. The recipient and beneficiary of these rights remains the State Treasury, represented by the Minister of National Defence. Due to the fact that the transfer of rights applies to all fields of use of the original elements, the State Treasury also has the right to obtain patents, protection rights or registration rights in the event of the development of an invention, utility model or industrial design.

In the opinion of the author and the increasing number of verdicts of administrative courts, the free transfer of rights to original items and other intangible assets to the State Treasury - if they arise - does not constitute both a paid supply of goods and a paid provision of services subject to VAT. No payment is due to, inter alia, the fact that the creation of authors elements is, in principle, a possible, albeit uncertain result of research and development work carried out under a project. The uncertainty of obtaining a positive result is, in turn, a natural feature of research projects. Therefore, the agreements concluded with NCBR directly indicate that future transfer of rights to intangible assets to the Treasury (if there are any) will be free of charge. Thus, the potential future transfer of rights to intangible assets to the State Treasury cannot be considered as the provision of services for consideration within the meaning of art. $5 \mathrm{sec}$. 1 point 1 of the VAT Act. The very provision of the contract with NCBR, referring to the transfer of proprietary copyrights, does not constitute a justified basis for considering the transfer of rights as a free service, which may be equated to a paid service pursuant to art. $8 \mathrm{sec}$. 2 of the VAT Act. At this point, it is worth referring to the individual interpretation of 9 September 2013, No. IPPP2/443$645 / 13-2 / D G$, in which we read that "(...) in a situation where, as a result of the works carried out in connection with the described project, their effect will be an object subject to the provisions of the Copyright Act, then upon completion of the project, the applicant will be obliged to transfer all the rights to the State Treasury free of charge. Thus, there will be no delivery of goods or provision of taxable services, because in the presented situation the condition for payment will not be met" [20].

A similar position is presented by the jurisprudence of the Provincial Administrative Court and the Supreme Administrative Court, which more and more often examines cases concerning the taxation of subsidies granted for the implementation of research and development projects - which shows the scale of tax problems faced by the scientific consortia. In the verdict of 21 March 2019 (I FSK 1363/18), the Supreme Administrative Court found that “(...) the proprietary copyrights resulting from the implementation of the project are owned by the State Treasury,

\section{Przeniesienie autorskich praw majątkowych na Skarb Państwa}

Umowy zawierane przez konsorcja naukowe z NCBR przewidują, że jeżeli w wyniku badań naukowych i prac rozwojowych prowadzonych przez konsorcjantów powstaną elementy autorskie, wówczas z chwilą zakończenia projektu nastąpi nieodpłatne przeniesienia ich na rzecz Skarbu Państwa. Przeniesienie praw obejmuje również wszelkiego rodzaju uzupełnienia tych elementów, ich modyfikacje, uszczegółowienia w zakresie wszelkich znanych i możliwych sposobów i pól eksploatacji lub dalszego transferu. Odbiorcą i beneficjentem tych praw pozostaje Skarb Państwa reprezentowany przez Ministra Obrony Narodowej. W związku z tym, że przeniesienie praw dotyczy wszelkich pól eksploatacji elementów autorskich, dlatego też Skarbowi Państwa przysługują również prawa do uzyskania patentów, prawa ochronne lub prawa z rejestracji w przypadku opracowania wynalazku, wzoru użytkowego lub wzoru przemysłowego.

W ocenie autorki oraz coraz liczniejszych orzeczeń sądów administracyjnych, nieodpłatne przeniesienie na Skarb Państwa praw do elementów autorskich i innych wartości niematerialnych - jeżeli takie powstaną - nie stanowi zarówno odpłatnej dostawy towarów, jak też odpłatnego świadczenia usług, podlegających opodatkowaniu VAT. Brak odpłatności wynika m.in. stąd, że powstanie elementów autorskich jest co do zasady możliwym, aczkolwiek niepewnym skutkiem badań naukowych i prac rozwojowych prowadzonych w ramach projektu. Niepewność uzyskania pozytywnego rezultatu jest $z$ kolei naturalną cechą projektów o charakterze naukowo-badawczym. Dlatego też umowy zawierane z NCBR wskazują wprost, że przyszłe przeniesienie praw do wartości niematerialnych na rzecz Skarbu Państwa (o ile w ogóle takie powstaną), nastąpi nieodpłatnie. Tym samym potencjalne przyszłe przeniesienie praw do wartości niematerialnych na Skarb Państwa nie może zostać uznane za odpłatne świadczenie usług w rozumieniu art. 5 ust. 1 pkt 1 ustawy o VAT. Sam zapis umowy z NCBR, mówiący o przeniesieniu autorskich praw majątkowych, nie stanowi uzasadnionej podstawy do uznania przeniesienia praw za świadczenie nieodpłatne, które może zostać zrównane ze świadczeniem odpłatnym na podstawie art. 8 ust. 2 ustawy o VAT. Warto w tym miejscu odwołać się do interpretacji indywidualnej $z$ dnia 9 września 2013 r. nr IPPP2/443-645/13-2/DG, w której czytamy, że "(...) w sytuacji, gdy wskutek prowadzonych prac w związku z opisanym projektem ich efekt będzie stanowił przedmiot podlegający przepisom ustawy o prawie autorskim, wówczas z chwilą zakończenia projektu, wnioskodawca zobowiązany będzie do nieodpłatnego przeniesienia na Skarb Państwa wszelkich praw. Tym samym więc nie dojdzie do dostawy towaru ani do świadczenia usług podlegających opodatkowaniu, bowiem w przedstawionej sytuacji nie zostanie spełniony warunek odpłatności" [20].

Podobne stanowisko prezentuje orzecznictwo WSA i NSA, które coraz częściej rozpoznaje sprawy dotyczące opodatkowania dotacji przyznanych na realizację projektów badawczo-rozwojowych - co pokazuje skalę problemów podatkowych, z jakimi borykają się konsorcja naukowe. W wyroku z dnia 21 marca 2019 r. (I FSK 1363/18) Naczelny Sąd Administracyjny uznał, że „(...) właścicielem autorskich praw majątkowych powstałych w wyniku wykonania 
and the transfer of proprietary copyrights to the represented State Treasury by the Minister of National Defence will be free of charge. One should also agree with the court of first instance that there are also no grounds for determining the commercial purpose of the project. From the point of view of the leader and participants of the consortium, the goal is to use the know-how developed in the future in the conducted business, to produce modern guided missiles or to sub-license other entities" [11] (see verdict of the Provincial Administrative Court of 27 November 2018; I SA/Gd 958/18 [21]).

\section{Deduction of input tax}

Moving on to the issue of the consortium's use of the possibility of deducting the input tax included in the price of goods and services used for the execution of the project, it is necessary to interpret art. $86 \mathrm{sec}$. 1 of the VAT Act in terms of the provisions of the standard agreement with NCBR.

The basic principles of deducting input tax have been formulated in art. $86 \mathrm{sec}$. 1 of the Act. According to the provision mentioned above, to the extent that the goods and services are used to perform taxable activities, the taxpayer referred to in art. 15 of the Act, has the right to reduce the amount of tax due by the amount of input tax, subject to art. 114, art. 119 par. 4, art. 120 sec. 17 and 19 and art. 124.

Pursuant to art. $86 \mathrm{sec} .2$ point 1 of the VAT Act, the amount of input tax is the sum of the tax amounts resulting from the invoices received by the taxpayer for the purchase of goods and services and for the payment of all or part of the payment before the purchase of goods or the provision of a service. It can be concluded from the above provisions that the right to reduce the amount of tax due by the amount of input tax is due when certain conditions are met, i.e. the deduction is made by the taxpayer of value added tax and the goods and services on which the tax was charged, are used to perform taxable activities, i.e. those which result in the determination of the tax due (creation of a tax liability). Therefore, the above rule excludes the possibility of reducing the amount of tax due by the amount of input tax related to goods and services that are not used for taxable activities, i.e. in the case of their use for activities exempt from VAT and not subject to this tax. It should be noted that when formulating in art. $86 \mathrm{sec} .1$ the condition of connection with taxable sales, the legislator does not make the right to deduct dependent on the connection of the purchase with currently performed taxable activities. It is sufficient that the circumstances surrounding the purchase of goods or services, taking into account the type of business activity conducted by the taxpayer, show that these purchases are made for the purpose of using them in the framework of his/her taxable activity. Therefore, in each case, it is necessary to assess whether the intention of the taxpayer performing specific activities with tax and legal consequences was to perform taxable activities. Moreover, it should be emphasized that the legislator created the right to the taxpayer to deduct input tax in whole or in part, provided that he/she meets both the positive conditions resulting from art. $86 \mathrm{sec} .1$ of the Act and projektu jest Skarb Państwa, a przeniesienie autorskich praw majątkowych na rzecz Skarbu Państwa reprezentowanego przez Ministra Obrony Narodowej nastąpi nieodpłatnie. Zgodzić się należy również z sądem pierwszej instancji, że brak jest też podstaw do dopatrywania się celu komercyjnego przedsięwzięcia. Z punktu widzenia lidera i uczestników konsorcjum celem jest wykorzystanie wypracowanego know-how w przyszłości w prowadzonej działalności gospodarczej, do produkcji nowoczesnych rakiet sterowanych lub udzielenia sublicencji innym podmiotom" [11] (por. wyrok WSA z dnia 27 listopada 2018 r., I SA/Gd 958/18 [21]).

\section{Odliczenie podatku naliczonego}

Przechodząc do kwestii skorzystania przez konsorcjum z możliwości odliczenia podatku naliczonego zawartego w cenie towarów i usług wykorzystywanych do realizacji projektu, należy dokonać wykładni art. 86 ust. 1 ustawy o VAT w kontekście zapisów standardowej umowy z NCBR.

Podstawowe zasady dotyczące odliczania podatku naliczonego zostały sformułowane w art. 86 ust. 1 ustawy. Zgodnie z ww. przepisem, w zakresie, w jakim towary i usługi są wykorzystywane do wykonywania czynności opodatkowanych, podatnikowi, o którym mowa w art. 15 ustawy, przysługuje prawo do obniżenia kwoty podatku należnego o kwotę podatku naliczonego, z zastrzeżeniem art. 114 , art. 119 ust. 4, art. 120 ust. 17 i 19 oraz art. 124.

Stosownie do art. 86 ust. 2 pkt 1 ustawy o VAT, kwotę podatku naliczonego stanowi suma kwot podatku wynikających z faktur otrzymanych przez podatnika z tytułu nabycia towarów i usług oraz dokonania całości lub części zapłaty przed nabyciem towaru lub wykonaniem usługi. Z powyższych przepisów wynika zatem, że prawo do obniżenia kwoty podatku należnego o kwotę podatku naliczonego przysługuje wówczas, gdy zostaną spełnione określone warunki, tzn. odliczenia tego dokonuje podatnik podatku od towarów i usług oraz gdy towary i usługi, z których nabyciem podatek został naliczony, są wykorzystywane do wykonywania czynności opodatkowanych, tzn. takich, których następstwem jest określenie podatku należnego (powstanie zobowiązania podatkowego). Przedstawiona wyżej zasada wyklucza zatem możliwość dokonania obniżenia kwoty podatku należnego o kwotę podatku naliczonego związanego $\mathrm{z}$ towarami i usługami, które nie są wykorzystywane do wykonywania czynności opodatkowanych, czyli w przypadku ich wykorzystania do czynności zwolnionych od podatku VAT oraz niepodlegających temu podatkowi. Należy zauważyć, że formułując $w$ art. 86 ust. 1 warunek związku ze sprzedażą opodatkowaną, ustawodawca nie uzależnia prawa do odliczenia od powiązania zakupu z obecnie wykonywanymi czynnościami opodatkowanymi. Wystarczającym jest, że z okoliczności towarzyszących nabyciu towarów lub usług przy uwzględnieniu rodzaju prowadzonej przez podatnika działalności gospodarczej wynika, że zakupy te dokonane są w celu ich wykorzystania w ramach jego działalności opodatkowanej. W każdym przypadku należy zatem dokonać oceny, czy intencją podatnika wykonującego określone czynności, z którymi łączą się skutki prawnopodatkowe, było wykonywanie czynności opodatkowanych. 
the absence of negative premises referred to in art. 88 of the Act. This provision specifies a list of exceptions that deprive the taxpayer of the right to reduce the amount of tax due by the amount of input tax. Therefore, if the funds received for the implementation of the research and development project are allocated by consortium members:

- solely for research costs,

- the goals achieved by the members of the consortium are not commercial in nature,

- the research results are not currently and will not be sold in the future, nor will they be used to perform activities subject to VAT,

then there are no reasonable grounds for the consortium to exercise the right to deduct.

From the wording of art. 86 of the VAT Act, it can be concluded that the legislator allowed the deduction of input tax only to the extent that goods and services are used to perform taxable activities. Input tax related to taxable transactions of the taxpayer can therefore be fully deducted. Thus, the indicated rule excludes the possibility of deducting input tax related to goods and services that are not used at all for taxable activities, i.e. in the case of their use for tax-exempt activities and not subject to this tax. A similar view was expressed by the Provincial Administrative Court in Warsaw in the verdict of 15 April 2019 (III SA/Wa 2340/18) [22] and the tax authority in the still valid individual interpretation of 28 January 2015, No. IPPP1/443-1266/14 -4/EK, in which we read: “(...) in the part in which the expenses incurred in connection with the execution of the Agreement will be used to perform non-taxable activities - free transfer of rights to the State Treasury in (if the project is successfully completed), the Applicant is not entitled to reduce the amount of tax due by the amount of input tax. Thus, it cannot be agreed with the Applicant that in relation to purchases used by the Applicant under the Agreement, he/she is entitled to a full deduction of the input tax" [23].

When interpreting art. $86 \mathrm{sec}$. 2a et seq. of the VAT Act, it is worth recalling the position of the Supreme Administrative Court, presented in the verdict of 17 April 2019 (I FSK 411/17) [24]. In the opinion of the Supreme Administrative Court, from the analysis of art. $86 \mathrm{sec}$. $2 a$ and $2 b$ of the Value Added Tax Act it is clear that the regulations mentioned above indicate the method of determining the proportions most suited to the specificity of the taxpayer's activity and the acquisitions made by him/her. The choice of a specific method of determining the proportion according to these premises rests with the taxpayer, but this does not preclude the authority from taking into account the information presented in the application for interpretation and providing the taxpayer with guidelines enabling the choice of a method that will meet the conditions of art. $86 \mathrm{sec}$. $2 \mathrm{~b}$ of the VAT Act, and thus will best suit the nature of the taxpayer's business and acquisitions.

In case of consortia implementing projects in the area of "Security and Defence", the basic element providing the basis for deducting the tax included in the price of goods or services will be the fact of performing activities subject to VAT. Of course, the right to deduct may vary as the consortium may adopt its own commercialization model. For instance, commercialization can
Ponadto podkreślić należy, że ustawodawca stworzył podatnikowi prawo do odliczenia podatku naliczonego w całości lub w części, pod warunkiem spełnienia przez niego zarówno przesłanek pozytywnych, wynikających z art. 86 ust. 1 ustawy oraz niezaistnienia przesłanek negatywnych, określonych w art. 88 ustawy. Przepis ten określa listę wyjątków, które pozbawiają podatnika prawa do obniżenia kwoty podatku należnego o kwotę podatku naliczonego. Jeżeli zatem środki otrzymane na realizację projektu badawczo-rozwojowego są przeznaczone przez konsorcjantów:

- wyłącznie na pokrycie kosztów badań naukowych,

- cele osiągnięte przez członków konsorcjum nie mają charakteru komercyjnego,

- wyniki badań nie są obecnie i nie będą w przyszłości zarówno przedmiotem sprzedaży, jak też nie będą wykorzystywane do wykonywania czynności opodatkowanych podatkiem VAT,

to wówczas brak jest uzasadnionych przesłanek do skorzystania przez konsorcjum z prawa do odliczenia.

Z brzmienia art. 86 ustawy o VAT wynika, że ustawodawca zezwolił na odliczenie podatku naliczonego wyłącznie w zakresie, w jakim towary i usługi służą wykonywaniu czynności opodatkowanych. Odliczyć można zatem w całości podatek naliczony, który jest związany z transakcjami opodatkowanymi podatnika. Wskazana zasada wyłącza tym samym możliwość dokonywania odliczeń podatku naliczonego związanego z towarami i usługami, które nie są w ogóle wykorzystywane do czynności opodatkowanych, czyli w przypadku ich wykorzystywania do czynności zwolnionych od podatku oraz niepodlegających temu podatkowi. Podobny pogląd wyraził WSA w Warszawie w wyroku $z$ dnia 15 kwietnia 2019 r. (III SA/Wa 2340/18) [22] oraz organ podatkowy w nadal aktualnej interpretacji indywidualnej $z$ dnia 28 stycznia 2015 r. nr IPPP1/443-1266/14-4/EK, w której czytamy. "(...) w części, w jakiej poniesione wydatki w związku z realizacją Umowy będą służyć do wykonywania czynności niepodlegających opodatkowaniu - nieodpłatne przekazanie praw na rzecz Skarbu Państwa w (przypadku pozytywnego zakończenia prac nad projektem), Wnioskodawcy nie przysługuje prawo do obniżenia kwoty podatku należnego o kwotę podatku naliczonego. Tym samym nie można zgodzić się z Wnioskodawcą, że w stosunku do zakupów wykorzystywanych przez Wnioskodawcę w ramach Umowy ma on prawo do pełnego odliczenia podatku naliczonego" [23].

Dokonując wykładni art. 86 ust. 2a i nast. ustawy VAT, warto przywołać stanowisko Naczelnego Sądu Administracyjnego, zaprezentowane w wyroku z dnia 17 kwietnia 2019 r. (I FSK 411/17) [24]. W ocenie NSA, z analizy art. 86 ust. 2a i 2b ustawy o podatku od towarów i usług wynika jednoznacznie, że ww. przepisy wskazują sposób określenia proporcji najbardziej odpowiadających specyfice wykonywanej przez podatnika działalności i dokonywanych przez niego nabyć. Wybór konkretnego sposobu określenia proporcji według tych przesłanek należy do podatnika, przy czym nie wyklucza to sytuacji, aby organ uwzględnił informacje przedstawione we wniosku o interpretację i dostarczył podatnikowi wskazówek umożliwiających wybór sposobu, który będzie spełniał warunki $z$ art. 86 ust. 2b ustawy o VAT i tym samym będzie najbardziej odpowiadał specyfice prowadzonej przez podatnika działalności i dokonywanych nabyć. 
be performed by the consortium leader sharing the profit with other members who will not be entitled to a deduction of input tax. If, on the other hand, the leader takes over from the consortium members the rights to the research results and commercializes them, then we will deal with a contractor-subcontractor relationship, and under VAT there will be all the effects related to the paid services referred to in art. $8 \mathrm{sec}$. 1 of the Act on tax on goods and services. Therefore, various variants of action are possible, which will determine the method of VAT settlement in projects financed by NCBR through subsidies.

Obviously, the issues discussed in this publication do not exhaust all problems related to VAT settlements in projects financed from the state budget. Despite similarities, due to the fact that the issues in each case are usually even slightly different, it is difficult to find a universal solution to all tax problems. Therefore, the article indicates doubts that are most often raised by consortium members both in discussions with tax authorities and in complaints filed with administrative courts of both instances.
W przypadku konsorcjów realizujących projekty w obszarze "Bezpieczeństwo i Obronność" zasadniczym elementem dającym podstawę do odliczenia podatku zawartego w cenie towarów lub usług będzie okoliczność wykonywania czynności podlegających opodatkowaniu VAT. Oczywiście prawo do odliczenia może kształtować się różnie, gdyż konsorcjum może przyjąć własny model komercjalizacji. Dla przykładu, komercjalizacji może dokonać lider konsorcjum, dzieląc się zyskiem z pozostałymi członkami, którym nie będzie przysługiwało prawo do odliczenia podatku naliczonego. Jeżeli z kolei lider przejmie od członków konsorcjum prawa do wyników badań i dokona ich komercjalizacji, wówczas będziemy mieli do czynienia z relacją wykonawca -podwykonawcy, a na gruncie podatku VAT zaistnieją wszystkie skutki, jakie wiążą się z odpłatnym świadczeniem usług, o których mowa w art. 8 ust. 1 ustawy o podatku od towarów i usług. Możliwe są zatem różne warianty działania, które będą determinowały sposób rozliczenia VAT $w$ projektach finansowanych przez NCBR w drodze dotacji.

Zagadnienia omawiane w niniejszej publikacji nie wyczerpują oczywiście wszystkich problemów związanych z rozliczeniem VAT w projektach finansowanych ze środków budżetu państwa. W związku z tym, że stany faktyczne w każdej sprawie, mimo podobieństw, są zazwyczaj choćby minimalnie różne, trudno znaleźć uniwersalne rozwiązanie wszystkich problemów podatkowych. Dlatego też w artykule wskazano na te wątpliwości, które są najczęściej podnoszone przez konsorcjantów zarówno w dyskusjach z organami podatkowymi, jak i w skargach kierowanych do sądów administracyjnych obu instancji.

[7] Ustawa z dnia 30 kwietnia 2010 r. o Narodowym Centrum Badań i Rozwoju (tj. Dz.U. z 2020 r., poz. 1861).

[8] Interpretacja indywidualna Dyrektora Krajowej Informacji Skarbowej z dnia 11 lutego 2016 r. nr ITPP2/ 4512-1086/15EK.

[9] Wyrok WSA z dnia 5 stycznia 2017 r. (I SA/Wr 1120/16).

[10] Wyrok NSA z dnia 31 lipca 2020 r. (I FSK 1792/17).

[11] Wyrok NSA z dnia 21 marca 2019 r. (I FSK 1363/18).

[12] Wyrok Trybunał Sprawiedliwości Unii Europejskiej z dnia 22 listopada 2001 r. w sprawie C-184/00 Office des Produits Wallons ASBL v. Belgian State (ECR 2001/11B/I-9115).

[13] Wyrok WSA z dnia 13 czerwca 2017 r. (I SA/Bd 474/17);

[14] Bartosiewicz A., VAT. Komentarz, Wyd. X, Wolters Kluwer, Warszawa 2016.

[15] Wyrok NSA z dnia 17 czerwca 2009 r. (I FSK 571/08).

[16] Wyrok NSA z dnia 5 lutego 2015 r. (I FSK 821/13).

[17] Wyrok WSA w Gliwicach z dnia 21 czerwca 2016 r. (III SA/ GI 232/16). ści dodanej (Dz.Urz.UE.L Nr 347, s. 1, ze zm.). 
[18] Kamiński A., Dotacje z funduszy UE a VAT, „Przegląd Podatkowy" 2005, 4, 31-35.

[19] Wyroki TSUE (numery spraw: C-498/99, publ. LEX nr 83900, C-16/93, publ. LEX nr 83886, C-89/81, publ. www.curia. europa.eu, czy C-154/80, publ. www.curia.europa.eu).

[20] Interpretacja indywidualna Dyrektora Krajowej Informacji Skarbowej z dnia 9 września 2013 r. nr IPPP2/443-645/ 13-2/DG.

[21] Wyrok WSA z dnia 27 listopada 2018 r. (I SA/Gd 958/18).

[22] Wyrok WSA w Warszawie w wyroku z dnia 15 kwietnia 2019 r. (III SA/Wa 2340/18).
[23] Interpretacja indywidualna Dyrektora Krajowej Informacji Skarbowej z dnia 28 stycznia 2015 r. nr IPPP1/ 443-1266/14-4/EK.

[24] Wyrok NSA z dnia 17 kwietnia 2019 r. (I FSK 411/17).

[25] Ustawa z dnia 20 lipca 2018 r. - Prawo o szkolnictwie wyższym i nauce (tj. Dz U. z 2020 r., poz. 85, ze zm.).

[26] Wyszomirska-Łapczyńska M., Zaskarżenie decyzji podatkowej, C.H. Beck, Warszawa 2014.

[27] Wyszomirska-Łapczyńska M., Pisma urzędowe i pisma procesowe. Komentarz do Ordynacji podatkowej, C.H. Beck, Warszawa 2019.
MONIKA WYSZOMIRSKA, PH.D. - PH.D. in law at the University of Warsaw, attorney-at-law, economist. She specializes in tax, financial, administrative and civil law, including among others research projects and development works as well as large IT projects. Author of 7 books on tax issues and over 250 press articles on substantive and procedural tax and administrative law. She has extensive experience in both drafting legal opinions and analyses, as well as representing parties before the Provincial and Supreme Administrative Court and common courts of all instances. She also appears before the Constitutional Tribunal in matters related to subsidies and taxes.
DR MONIKA WYSZOMIRSKA - doktor nauk prawnych Uniwersytetu Warszawskiego, radca prawny, ekonomista. Specjalizuje się w prawie podatkowym, finansowym, administracyjnym i cywilnym, w tym m.in. w zakresie projektów naukowych i prac rozwojowych oraz dużych projektów informatycznych. Autorka 7 książek o tematyce podatkowej oraz ponad 250 artykułów prasowych poruszających kwestie dotyczące materialnego oraz procesowego prawa podatkowego i administracyjnego. Posiada bogate doświadczenie zarówno w sporządzaniu opinii i analiz prawnych, jak i reprezentowaniu stron przed Wojewódzkim i Naczelnym Sądem Administracyjnym oraz sądami powszechnymi wszystkich instancji. Występuje również przed Trybunałem Konstytucyjnym w sprawach dotyczących dotacji oraz podatków. 